\title{
Effect of pre-treatment on membrane fouling of PVDF (Polyvinylidene Fluoride) microfiltration membrane with different structures in a pilot-scale drinking water production system
}

\author{
S. R. Chae*, H. Yamamura*, K. Ikeda**, G. Ozawa*, Y. Watanabe* \\ * Division of Socio-Environmental Engineering, Graduate School of Engineering, Hokkaido University, \\ Kita 13, Nishi 8, Kita-ku, Sapporo 060-8628, Japan (E-mail: srchae@eng.hokudai.ac.jp; \\ hiroshi@eng.hokudai.ac.jp; ozawa@eng.hokudai.ac.jp; yoshiw@eng.hokudai.ac.jp) \\ ** Water Treatment Technology Center, Toray Industries, Inc., 3-3, Sonoyama 3-chome, Otsu, Shiga \\ 520-0842, Japan (E-mail: keiichi_ikeda@nts.toray.co.jp)
}

\section{ABSTRACT}

Two pilot-scale polyvinylidene fluoride (PVDF) microfiltration (MF) membranes with different structures (i.e. symmetric and asymmetric) were operated after coagulation/sedimentation, sand filtration, and chlorination. Turbidity was removed completely. Moreover, humic substances, $\mathrm{Al}$, and $\mathrm{Fe}$ were removed very well by the pilot-scale system. An asymmetric membrane (HFS membrane) having a nominal pore size of $0.05 \mu \mathrm{m}$ showed relatively high removal efficiency of the small organic matter (about 6,000 Da) than a symmetric membrane (HFM membrane) having a nominal pore size of $0.1 \mu \mathrm{m}$. However, the extracted inorganic concentrations of the HFM membrane were relatively higher than that of the HFS membrane. Therefore, it could be concluded that the HFS membrane better reduced membrane fouling than the HFM although the nominal pore size of the former was half of the latter. To control microbial growth and mitigate membrane fouling, a $\mathrm{NaOCl}$ solution was injected into the effluent of sand filtration before the both membranes. However, it adversly affected membrane fouling due to the oxidization of inorganic substances such as $\mathrm{Al}, \mathrm{Fe}$, and $\mathrm{Mn}$.

Keywords: PVDF; MF; symmetric; asymmetric; coagulation/sedimentation; sand filtration; chlorination; oxidization of inorganic substances.

\section{INTRODUCTION}

As a means of complying with current and anticipated regulations on drinking water production, membrane technologies have been widely adopted in the world. Especially, the low-pressure driven membranes such as microfiltration (MF) and ultrafiltration (UF) have attracted a considerable amount of attention in drinking water treatment to remove particulates and usually produce a filtrate free of turbidity and bacteria from river, lake, and underground waters (Hagen, 1998; Ma et al., 1998; Yuasa, 1998; Bian et al., 1999; Klijn et al., 2000; Kimura et al., 2004). Specially, the MF membrane could be adapted to be most requirements by easy modification in the chemical composition, which make low-cost production possible.

However, those MF and UF membranes are less effective in removing dissolved molecules such as humic and inorganic substances. To remove these substances and to mitigate membrane fouling, a hybrid membrane system combined with processes such as coagulation/sedimentation, ozonation, and activated carbon has been widely used. Especially, Jang et al. (2002 and 2005) applied a jet mixed separator (JMS) (Watanabe et al., 1998) as a coagulation/sedimentation unit for a polymerized polyacrylonitrile UF membrane having a nominal pore size of $0.01 \mu \mathrm{m}$. Use of the JMS with polysilicato-iron (PSI) as a coagulant extended the operation period by removing dissolved organic carbon (DOC) effectively.

On the other hand, a high permeability and high strength PVDF membrane was only recently developed for drinking water production (Yeh and Wang, 2004; Kurihara et al., 2004). Before the new membrane is fully ready for field application, however, it should be evaluated by long-term tests using natural raw water because the effectiveness of membrane filtration depends significantly on the raw water quality and the operating conditions. Therefore, this study was focused on process performance and 
fouling characteristics of two PVDF membranes with different structures (i.e. symmetric and asymmetric) after coagulation/sedimentation, sand filtration, and chlorination for drinking water production.

\section{MATERIAL AND METHODS}

\section{Characteristics of the raw water}

For this study, Chitose River surface water in the Kamiebetsu Water Purification Plant (Ebetsu City, Japan) was used as raw water. Although the water quality of Chitose River changed seasonally, it typically contains relatively high turbidity, humic and inorganic substances (Bian et al., 1999; Jang et al., 2002).

\section{Experimental set-up for pilot-scale PVDF membrane filtration systems}

As shown in Table 1, the pilot-scale PVDF membrane filtration system was composed of coagulation/sedimentation, sand filtration, and membrane filtration using two PVDF membranes (TORAY Industries, Inc., Japan) with different structures. One membrane (0.1 $\mu \mathrm{m}, \mathrm{HFM})$ is a symmetric membrane and the other is an asymmetric membrane $(0.05 \mu \mathrm{m}, \mathrm{HFS})$. Periodic backwashing for the both membranes was conducted as follows: 30 minutes filtration; 30 seconds backwash with permeate; one minute backwash with pressurized air; one minute idle; 30 seconds fill. Under these operating conditions, the overall recovery rate was found to be $98 \%$. To avoid temperature effects, the observed transmembrane pressure (TMP) was normalized to $25^{\circ} \mathrm{C}$ as Eq. (1):

$$
\Delta P_{25}=\Delta P_{t} \times \frac{\mu_{25}}{\mu_{t}}
$$

where $\Delta \mathrm{P}_{25}$ is the normalized TMP (Bar) at $25^{\circ} \mathrm{C}, \Delta \mathrm{P}_{\mathrm{t}}$ is the TMP (Bar) at $\mathrm{t}^{\circ} \mathrm{C}, \mu_{25}$ is the dynamic viscosity of permeate $(\mathrm{Pa} \cdot \mathrm{s})$ at $25^{\circ} \mathrm{C}$, and $\mu_{\mathrm{t}}$ is the dynamic viscosity of permeate $(\mathrm{Pa} \cdot \mathrm{s})$ at ${ }^{\circ} \mathrm{C}$.

Polysilicato-iron (PSI) and Polyaluminium chloride (PACl) were supplied as coagulants. In Runs 1 and 2 , to inactivate microorganisms and reduce membrane fouling, a sodium hypochlorite $(\mathrm{NaOCl})$ solution was added to target concentration of $1 \mathrm{mg} \mathrm{l}^{-1}$ in the membrane permeates.

Table 1. Operation conditions of the pilot-scale PVDF membrane filtration system

\begin{tabular}{|c|c|c|c|}
\hline Unit process & Run 1 & Run 2 & Run 3 \\
\hline Raw water & \multicolumn{3}{|c|}{ Chitose River surface water in Ebetsu, Japan } \\
\hline Coagulation/Sedimentation & \multicolumn{3}{|c|}{ JMS (Jet Mixed Separator) } \\
\hline $\begin{array}{l}\text { Hydraulic retention time } \\
\text { Coagulant } \\
\text { Dose } \\
\text { pH }\end{array}$ & $\begin{array}{l}84 \text { minute } \\
\text { Polysilicato-iron } \\
12 \mathrm{mg} \mathrm{l}^{-1} \text { as Fe } \\
6.5 \pm 0.2\end{array}$ & $\begin{array}{c}84 \text { minute } \\
\text { Polyaluminium chloride } \\
10 \mathrm{mg} \mathrm{l}^{-1} \text { as Al } \\
7.0 \pm 0.3\end{array}$ & $\begin{array}{c}84 \text { minute } \\
\text { Polyaluminium chloride } \\
10 \mathrm{mg} \mathrm{l}^{-1} \text { as } \mathrm{Al} \\
7.0 \pm 0.1\end{array}$ \\
\hline Sand filtration & \multicolumn{3}{|c|}{ Three layer sand filter (garnet, sand, and anthracite) } \\
\hline $\begin{array}{l}\text { Linear velocity } \\
\text { Backwashing interval }\end{array}$ & \multicolumn{3}{|c|}{$\begin{array}{c}100 \mathrm{~m} \mathrm{~d}^{-1} \\
\text { Every } 48 \text { hours }\end{array}$} \\
\hline Membrane filtration & \multicolumn{3}{|c|}{ PVDF hollow fiber membrane } \\
\hline $\begin{array}{l}\text { Nominal pore size } \\
\text { Operation mode } \\
\text { Surface area } \\
\text { Permeate flux } \\
\text { Physical cleaning }\end{array}$ & \multicolumn{3}{|c|}{$\begin{array}{l}0.1 \mu \mathrm{m} \text { (HFM) and } 0.05 \mu \mathrm{m} \text { (HFS) } \\
\text { Pressurized type } \\
7 \mathrm{~m}^{2} \\
2.5 \mathrm{~m} \mathrm{~d}^{-1} \text { (constant flow rate) } \\
30 \text { minute }\end{array}$} \\
\hline $\begin{array}{l}\text { Chlorination } \\
\text { Dose as } \mathrm{NaOCl}\end{array}$ & \multicolumn{2}{|c|}{ Before membrane filtration } & Not applied \\
\hline
\end{tabular}

\section{Extraction of inorganic foulants}

At the end of each run, chemical cleaning of two PVDF membranes was performed with $1 \mathrm{~N} \mathrm{HCl}$ for 2 hours, $5 \mathrm{~g} \mathrm{l}^{-1} \mathrm{NaOCl}$ for 3 hours, and $20 \mathrm{~g} \mathrm{l}^{-1}$ oxalic acid for 3 hours. 


\section{Analytical methods}

Turbidity was analyzed using an integration ball type turbidity meter (SEP-PT-706D, Mistubishi Chemical, Japan) after ultra-sonification for 10 seconds. Total organic carbon (TOC) and DOC were measure by a TOC meter (TOC-5000A, Shimadzu, Japan). To check temperature and $\mathrm{pH}$, a portable $\mathrm{pH}$ meter (HM-12P, TOA electronics Ltd., Japan) was used. Humic substances (UV absorbance at $260 \mathrm{~nm}$, $\mathrm{UVA}_{260}$ ) were measured by UV/VIS spectrophotometer (U-2000, Hitachi, Japan) with a one cm cell. In particular, the UV absorbance and the DOC concentration of raw water were measured after removal of particulate matter using a $0.45 \mu \mathrm{m}$ PTFE (poly-tetrafluoroethylene) membrane (Millipore, U.S.A.). Free chlorine concentrations were determined by the n,n-diethyl-p-phenylene diamine (DPD) colorimetric method using reagent pillows.

The characteristics of inorganic substances were determined using a membrane fractionation method. Each sample was fractionated using a series of and microfiltration (mixed cellulose esters for 8, 0.45, 0.1, $0.05 \mu \mathrm{m}$, Millipore, U.S.A) and ultrafiltration membranes (polysulfone for $100 \mathrm{kDa}$, Alfaraval, Norway). Inorganic substances such as $\mathrm{Al}, \mathrm{Mn}$, and $\mathrm{Fe}$ were determined by an inductively coupled plasma atomic emission spectrophotometer (ICPS-7500, Shimadzu, Japan).

Molecular weight distribution of dissolved organic matter in water samples was determined by liquid chromatography (Hitachi, Japan) with UV (Hitachi L-4000, Japan) and online organic carbon detectors (Sievers 810 turbo portable total organic carbon analyzer) having two size exclusion chromatography columns in order to separate organic molecules according to their molecular size.

\section{RESULTS AND DISCUSSION}

\section{Performance of the pilot-scale PVDF membrane filtration system}

As shown in Table 2, most of the turbidity (94\%), humic substances (75\%), and total Al (90\%) were removed by the pre-coagulation/sedimentation in Run 1. Total Fe was mostly removed (about $70 \%$ ) by the sand filtration. However, removal efficiencies of TOC by the pre-treatment were only $48 \%$.

Table 2. Characteristics of influent and membrane permeates in the pilot-scale system

\begin{tabular}{|c|c|c|c|c|c|}
\hline Run 1 & Raw water & $\begin{array}{l}\text { Effluent of } \\
\text { coag./sed. }\end{array}$ & $\begin{array}{c}\text { Effluent of } \\
\text { SF }\end{array}$ & $\begin{array}{l}\text { Permeate of } \\
\text { the HFM }\end{array}$ & $\begin{array}{c}\text { Permeate of } \\
\text { the HFS }\end{array}$ \\
\hline Turbidity & $13.1 \pm 4.4$ & $0.8 \pm 0.3$ & 0 & 0 & 0 \\
\hline $\mathrm{UVA}_{260}\left(\mathrm{~cm}^{-1}\right)$ & $0.08 \pm 0.02$ & $0.02 \pm 0.01$ & $0.01 \pm 0.01$ & $0.01 \pm 0.01$ & $0.01 \pm 0.01$ \\
\hline TOC $\left(\mathrm{mg} \mathrm{l}^{-1}\right)$ & $2.5 \pm 1.1$ & $1.5 \pm 0.5$ & $1.3 \pm 0.6$ & \multirow{2}{*}{$1.2 \pm 0.7$} & \multirow{2}{*}{$1.0 \pm 0.5$} \\
\hline $\mathrm{DOC}\left(\mathrm{mg} \mathrm{l}^{-1}\right)$ & $2.1 \pm 1.0$ & $1.3 \pm 0.6$ & $1.2 \pm 0.6$ & & \\
\hline Total-Al (ppb) & $196 \pm 113$ & $19 \pm 18$ & $9 \pm 7$ & $9 \pm 3$ & $5 \pm 4$ \\
\hline Total-Fe (ppb) & $472 \pm 181$ & $351 \pm 129$ & $6 \pm 2$ & $3 \pm 2$ & $3 \pm 2$ \\
\hline Total-Mn (ppb) & $194 \pm 76$ & $309 \pm 114$ & $294 \pm 103$ & $279 \pm 109$ & $271 \pm 96$ \\
\hline Run 2 & Raw water & $\begin{array}{l}\text { Effluent of } \\
\text { coag./sed. }\end{array}$ & $\begin{array}{c}\text { Effluent of } \\
\text { SF }\end{array}$ & $\begin{array}{l}\text { Permeate of } \\
\text { the HFM }\end{array}$ & $\begin{array}{c}\text { Permeate of } \\
\text { the HFS }\end{array}$ \\
\hline Turbidity & $18.5 \pm 14.5$ & 0.2 & 0 & 0 & 0 \\
\hline $\mathrm{UVA}_{260}\left(\mathrm{~cm}^{-1}\right)$ & $0.10 \pm 0.04$ & $0.02 \pm 0.01$ & $0.01 \pm 0.01$ & $0.01 \pm 0.01$ & $0.01 \pm 0.01$ \\
\hline TOC $\left(\mathrm{mg} \mathrm{l}^{-1}\right)$ & $1.6 \pm 0.5$ & $1.0 \pm 0.2$ & $0.9 \pm 0.2$ & \multirow{2}{*}{$0.8 \pm 0.3$} & \multirow{2}{*}{$0.8 \pm 0.2$} \\
\hline $\mathrm{DOC}\left(\mathrm{mg} \mathrm{l}^{-1}\right)$ & $1.4 \pm 0.5$ & $0.9 \pm 0.2$ & $0.8 \pm 0.2$ & & \\
\hline Total-Al (ppb) & $125 \pm 51$ & $353 \pm 62$ & $20 \pm 4$ & $12 \pm 4$ & $15 \pm 5$ \\
\hline Total-Fe (ppb) & $621 \pm 349$ & $46 \pm 15$ & $27 \pm 6$ & $20 \pm 6$ & $22 \pm 5$ \\
\hline Total-Mn (ppb) & $111 \pm 53$ & $94 \pm 28$ & $70 \pm 7$ & $26 \pm 6$ & $23 \pm 3$ \\
\hline
\end{tabular}

In Run 2, average removal efficiencies of turbidity and humic substance by the precoagulation/sedimentation were $99 \%$ and $80 \%$, respectively. Accordingly, about $93 \%$ of total Fe was removed by the pre-coagulation/sedimentation and most of Al was effectively rejected by the sand filtration. However, removal efficiencies of TOC and Mn by the pre-treatment were only $44 \%$ and $37 \%$, respectively, because these substances mainly existed in dissolved form. Removal efficiency of $\mathrm{Mn}$ by both PVDF membranes was about $41 \%$. 


\section{Fouling characteristics of the pilot-scale PVDF membrane filtration system}

For membrane fouling tendency, as shown in Fig. 1, it took about 34 and 40 days to reach the TMP of 0.5 Bar in the HFM and the HFS membrane in Run 1, respectively. On the other hand, in Run 2, the TMP of the HFM membrane increased rapidly to 0.5 Bar after only 10 days, while the TMP of the HFS membrane increased gradually to 0.5 Bar up to 37 days. As a result, it could be concluded that the asymmetric membrane (HFS membrane) better reduced membrane fouling than the symmetric membrane (HFM membrane) although the nominal pore size of the former was half of the latter.
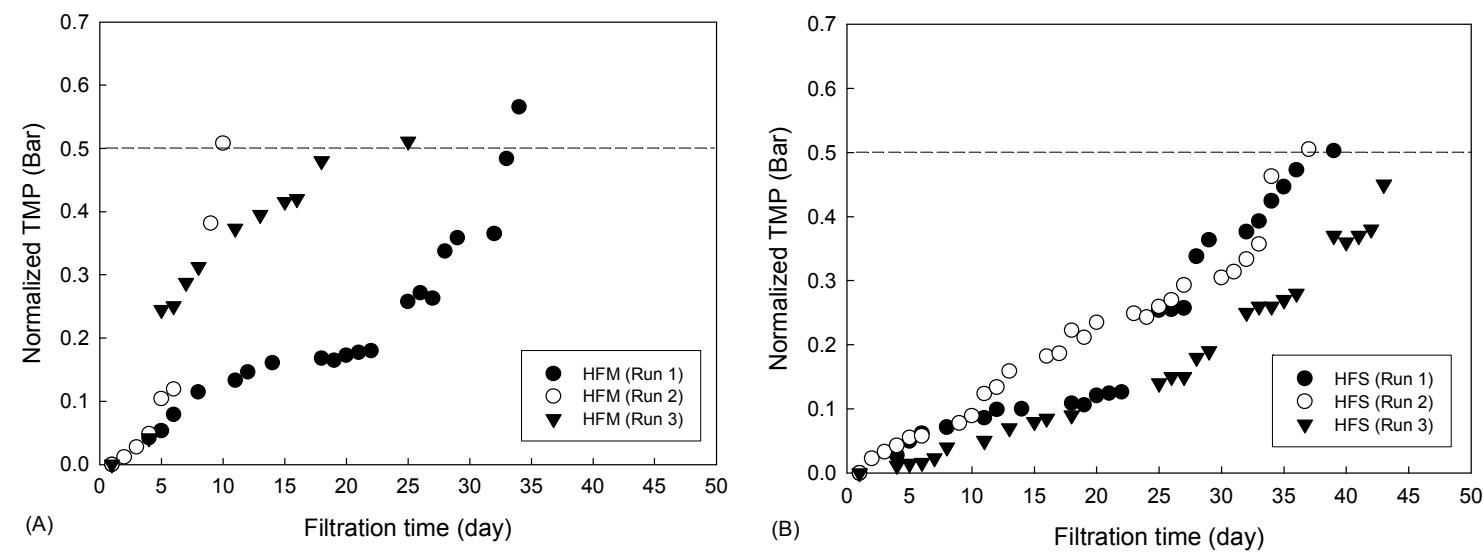

Fig. 1. Variations of TMPs of the HFM membrane (A) and the HFS membrane (B) in each run.

The both PVDF membranes showed different membrane fouling characteristics. In response to this concern, behaviors of organic and inorganic substances in the pilot-scale system were studied. In case of organic matter, as shown in the Fig. 2, there were two distinguish peaks in raw water and the treated water samples. Most of organic matter was less than 6,000 Da in raw water, while there was also a small fraction presented with molecular weight greater than one million $\mathrm{Da}$.

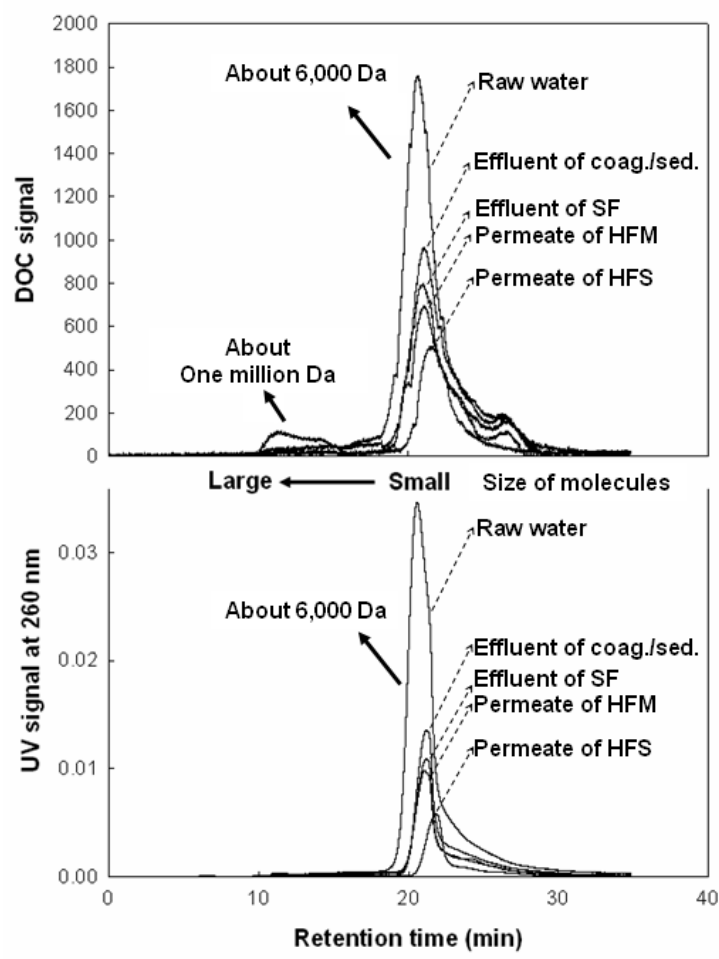

Fig. 2. Behaviors of organic matter and humic substances in the pilot-scale membrane filtration system. 
By the pre-treatment, the large organic fraction was effectively removed but the small organic matter (about 6,000 Da), which was mainly humic substances and might be adsorbed in the membrane, could not be effectively removed before the both membranes. The HFS membrane showed relatively high removal efficiency of this small organic matter than the HFM membrane.

Oxidation of raw water normally has been done using chlorine or ozone to control metals and microbial growth for potable water treatment. In this study, to inactivate microorganisms and reduce membrane fouling, the $\mathrm{NaOCl}$ solution was injected into the effluent of sand filtration before the both membranes. In the effluent of sand filtration, most of $\mathrm{Al}(95 \%), \mathrm{Fe}(87 \%)$, and $\mathrm{Mn}(99 \%)$ mainly existed in dissolved form (less than $0.45 \mu \mathrm{m}$ ). However, as compared with the results of Run 3 in Fig. 2, high fouling potential of the both membranes was monitored in Run 2 because inorganic substances such as $\mathrm{Al}, \mathrm{Fe}$, and $\mathrm{Mn}$ were oxidized by the pre-chlorination (Fig. 3).

Based on these results, it can be concluded that these characteristics of organic and inorganic substances resulted in different variations of TMP of the both PVDF membranes.

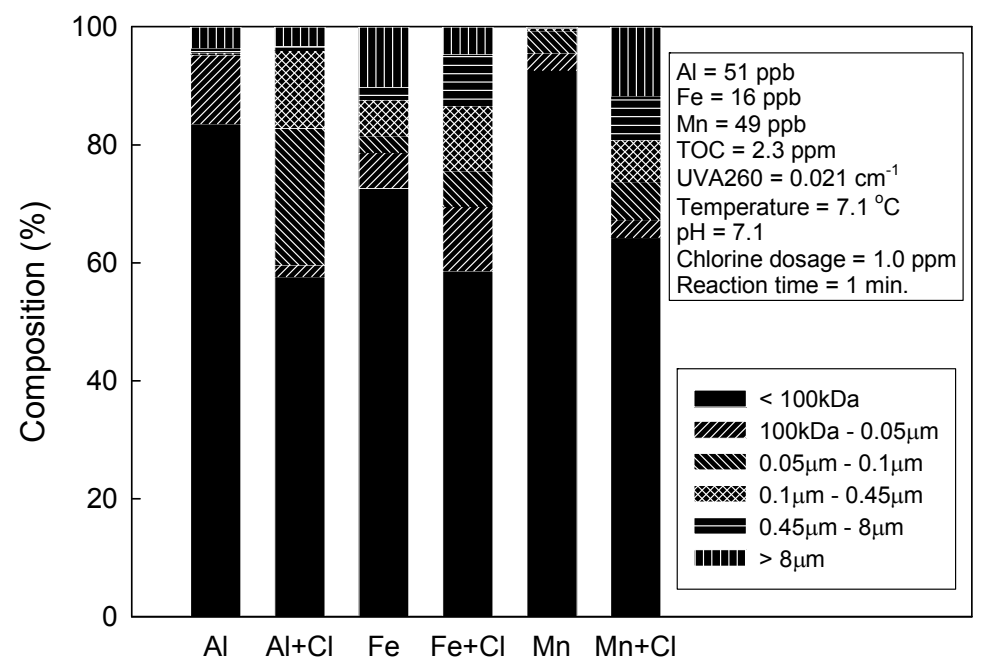

Fig. 3. Effect of chlorine on the oxidation of inorganic substances in the effluent of sand filtration.

At the end of each run, chemical cleaning of two PVDF membranes was performed with three chemicals. As a result, as shown in Fig. 4, it was found that Fe and Mn were major inorganic foulants in Run 1 and Run 2, respectively. Accordingly, the extracted inorganic concentrations of the HFM membrane were relatively higher than that of the HFS membrane in Runs 1 and 2.
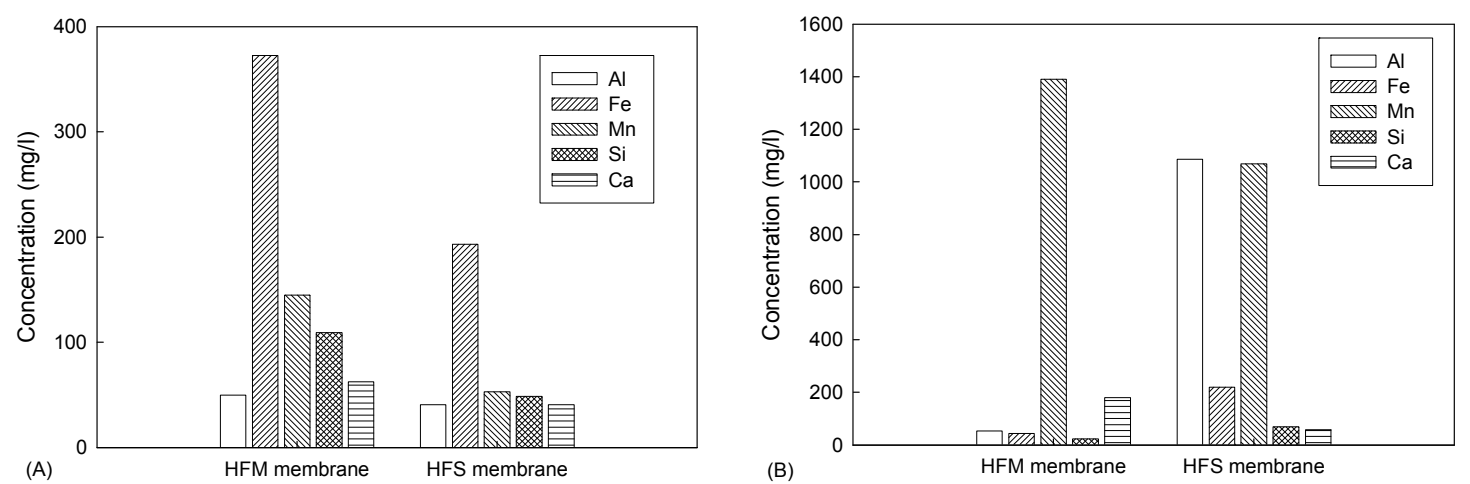

Fig. 4. Inorganic substances extracted by three chemical solutions after Runs 1 (A) and 2 (B).

According to the literature, $\mathrm{Fe}$ and $\mathrm{Mn}$ have been found to cause membrane fouling in the treatment of drinking water (Xu et al., 2004). The primary concern with elevated levels of dissolved iron and manganese in water is that when they become oxidized to insoluble ferric hydroxide, $\mathrm{Fe}(\mathrm{OH})_{3}$ and 
manganese dioxide, $\mathrm{MnO}_{2}$, they precipitate on the membrane and cause reddish-orange or black deposits, respectively (American Water Works Association, 1999).

Choo et al. (2005) found that a sharp rise of TMP occurred when the water was chlorinated in the presence of iron and manganese. Especially, the deposition of oxidized manganese precipitates was responsible for a greater amount of responsibility for membrane fouling. In this study, results shown in Fig. 1 and Fig. 4 indicate that the oxidized Mn by pre-chlorination also caused more severe membrane fouling than did the oxidized Fe.

In addition, the asymmetric membrane $(0.05 \mu \mathrm{m})$ was more effective at reducing membrane fouling than the symmetric membrane $(0.1 \mu \mathrm{m})$ although the nominal pore size of the former was smaller than that of the latter. From this result, it is thought that membrane fouling was mitigated in the HFS membrane due to the formation of much denser cake layer on the top of the membrane surface.

\section{CONCLUSIONS}

In this study, the process performance and fouling characteristics of two pilot-scale PVDF membranes with different structures (i.e. symmetric and asymmetric) were compared to produce potable water from Chitose River surface water containing high turbidity, humic and inorganic substances. As a result, the following conclusions are drawn:

1. Turbidity was removed completely by the proposed pilot-scale system. Humic substances, Al, and Fe were effectively removed by the pre-coagulation/sedimentation and sand filtration.

However, TOC and Mn were not effectively removed by the pre-treatment as these substances mainly existed in dissolved form.

2. The both membranes showed different fouling characteristics. The asymmetric membrane $(0.05 \mu \mathrm{m}$, HFS) better reduced membrane fouling than the symmetric membrane $(0.1 \mu \mathrm{m}, \mathrm{HFM})$ although the nominal pore size of the former was half of the latter.

The HFS membrane showed relatively high removal efficiency of the small organic matter (about $6,000 \mathrm{Da})$ than the HFM membrane. However, the extracted inorganic concentrations of the HFM membrane were relatively higher than that of the HFS membrane.

These results indicate that the formation of a dense cake layer on the top of the membrane provided benefits in terms of both pollutant removal and fouling mitigation.

3. To control microbial growth and mitigate membrane fouling, the $\mathrm{NaOCl}$ solution was injected into the effluent of sand filtration before the both membranes in Runs 1 and 2. However, compared with the results of Run 3 (without pre-chlorination), the pre-chlorination adversly affected membrane fouling due to the oxidization of $\mathrm{Fe}$ and $\mathrm{Mn}$.

Periodic backwashing with chlorine or acid solution to mitigate membrane fouling by inorganic substances will be discussed in a following manuscript.

\section{REFERENCES}

American Water Works Association (1999). Water quality and treatment, fifth edition, American Water Works Association, McGraw-Hill, Inc., U.S.A.

Bian, R., Watanabe, Y., Tambo, N. and Ozawa, G. (1999). Removal of humic substances by UF and NF membrane systems. Water Sci. Technol., 40(9), 121-129.

Choo, K. H., Lee, H., Choi, S. J. (2005). Iron and manganese removal and membrane fouling during UF in conjunction with prechlorination for drinking water treatment. J. Membr. Sci., 267(1-2), 18-26.

Hagen, K. (1998). Removal of particles, bacteria and parasites with ultrafiltration for drinking water treatment. Desalination, 119, 85-91.

Jang, N-Y, Watanabe, Y., Ozawa, G., and Hosoya, M. (2002). Effect of Pre-coagulation/sedimentation on the ultrafiltration membrane process. Chemical Water and Wastewater Treatment VII, 51-58, IWA Publishing, London.

Jang, N-Y, Watanabe, Y. and Minegishi, S. (2005). Performance of ultrafiltration membrane process combined with coagulation/sedimentation. Water Sci. Technol., 51(6-7), 209-219.

Klijn, R. B., van der Meer, W. G. J., Vriezen, H., van Ekkendonk, F. H. J. (2000). Surface water treatment with Zenon microfiltration membranes: minimisation of energy and chemical use. Desalination, 131, 337-343. 
Kimura, K., Hane, Y., Watanabe, Y., Amy, G., Ohkuma, N. (2004). Irreversible membrane fouling during ultrafiltration of surface water. Water Res., 38, 3431-3441.

Kurihara, M. Uemura, T., Matsuka, N. (2004). Poly (vinylidene fluoride) microfiltration hollow fiber membrane for drinking water treatment and its application. IWA World Water Congress, September 19 24, 2004, Marrakech.

Lee, S., Jang, N. and Watanabe, Y. (2004). Effect of residual ozone on membrane fouling reduction in ozone resisting microfiltration (MF) membrane system. Water Sci. Technol., 50(12), 287-292.

Ma, W., Sun, Z., Wang, Z., Feng, Y. B., Wang, T. C., Chan, U. S., Miu, C. H., Zhu, S. (1998). Application of membrane technology for drinking water. Desalination, 119, 127-131.

Taniguchi, M., Kilduff, J. E. and Belfort, G. (2003). Modes of natural organic matter fouling during ultrafiltration. Environ. Sci. Technol., 37, 1676-1683.

Watanabe, Y., Kasahara, S. and Iwasaki, Y. (1998). Enhanced flocculation/sedimentation process by a jet mixed separator. Water Sci. Technol., 37(10), 55-67.

Yeh, H. H. and Wang, W. H. (2004). A study on the fouling phenomena of MF membrane. IWA World Water Congress, September 19 24, 2004, Marrakech.

Yuasa, A. (1998). Drinking water production by coagulation - microfiltration and adsorption ultrafiltration. Water Sci. Technol., 37(10), 135-146.

$\mathrm{Xu}, \mathrm{W}$., Chellam, S., Clifford, D. A. (2004). Indirect evidence for deposit rearrangement during dead-end microfiltration of iron coagulated suspension. J. Membr. Sci., 239, 243-254. 